\title{
Potestad organizatoria y autonomía local
}

\author{
Juan Luis de la Vallina Velarde \\ Catedrático de Derecho Administrativo \\ Universidad de Oviedo
}

SUMARIO: 1. LA POTESTAD AUTO-ORGANIZATORIA DE LAS ENTIDADES LOCALES COMO EXPRESION DE SU AUTONOMIA. 2. LA AUTONOMIA LOCAL EN LA CONSTITUCION ESPAÑOLA DE 1978. 3. LA DISTRIBUCION DE COMPETENCIAS ENTRE EL ESTADO Y LAS COMUNIDADES AUTONOMAS EN MATERIA DE REGIMEN LOCAL. 4. LA CONFIGURACION DE LA POTESTAD ORGANIZATORIA DE LOS ENTES LOCALES EN EL ORDENAMIENTO JURIDICO ESPAÑOL. 4.1 Delimitacion previa. 4.2. Principios constitucionales en relacion al gobierno local. 4.3. El desarrollo de los principios constitucionales. 4.4. La potestad organizatoria en la LBRL. 5. LA SENTENCIA DEL TRIBUNAL CONSTITUCIONAL 214/1989, DE 21 DE DICIEMBRE, EN RELACION A LA POTESTAD ORGANIZATORIA DE LAS ENTIDADES LOCALES.

\section{LA POTESTAD AUTO-ORGANIZATORIA DE LAS ENTIDADES LOCALES COMO EXPRESION DE SU AUTONOMIA}

El examen de la potestad de los entes locales para decidir y establecer su propia organización se presenta en nuestro ordenamiento jurídico con una marcada complejidad que es, en cierta forma, consecuencia lógica del hecho de hacer referencia a un aspecto central de la posición institucional del régimen local.

Precisar el sentido y alcance del poder organizatorio interno de los entes locales 1 encuadrándolo adecuadamente, - precisando sus límites en función de las competencias que sobre el régimen local corresponden a las otras entidades territoriales superiores que forman

\footnotetext{
${ }^{1}$ La distinción entre poder organizatorio general o externo y poder organizatorio interno, en F. LOPEZ RAMON, "La potestado organizatoria de la Administración pública en el tránsito de un Estado autoritario a un Estado de Derecho", en Rev. Estudios de la Vida local, $n .^{\circ} 223$, págs 243-224. En relación a las Administraciones locales la potestad organizatoria externa haría referencia a la capacidad para reconocer la existencia de Entidades locales, que en nuestro ordenamiento jurídico se reparte entre el Estado (Entidades básicas o territoriales) y las Comunidades autónomas (entidades facultativas) (art. 3, Ley reguladora de las bases del Régimen local de 2 de abril de 1985) y cuyo estudio excede a los límites de este trabajo.
} 
parte de la organización política (Estado-comunidad), es decir, atendiendo a las competencias del propio Estado. (Estado-organización) 2 y a las que son propias de las Comunidades autónomas-, es una problemática no exenta de dificultad y que ofrece - como tendremos ocasión de ver- posicionamientos fuertemente encontrados. Y ello, dado que, como queda apuntado, la cuestión encierra el siempre dificil encuadramiento institucional de las entidades locales dentro de la organización territorial del Estado, que en nuestro caso diseña la Constitución de 1978, en relación a un aspecto concreto de indudable importancia, como es la capacidad de los entes locales para montar la estructura de gobierno y administración que estimen pertinente en función del logro de sus propios intereses. Importancia que queda resaltada si se tiene en cuenta que la organización se presenta, para la vigente ley reguladora de las bases del Régimen local (art. 11.2 de la ley 7/1985, de 2 de abril) (en adelante LBRL), como uno de los elementos constitutivos del municipio, junto al territorio y la población.

Esta importancia y trascendencia de la cuestión es la que hace de su estudio tema testigo, piedra de toque, para valorar y enjuiciar el papel y posición institucional de las entidades locales en el conjunto de la organización político-administrativa.

Con carácter general se puede partir de la idea de que las potestades atribuidas por el ordenamiento jurídico a las entidades locales y, por consiguiente, también la potestad de cuyo examen se trata, son consecuencia del reconocimiento constitucional de su autonomía, tal como se reconoce expresamente por el Tribunal Constitucional, en relación a la potestad normativa organizatoria local, en su Sentencia de 21 de diciembre de 1989 (Fundamento Jurídico 6) recaída en el recurso de inconstitucionalidad contra determinados preceptos de la LBRL.

La Constitución de 1978, como es bien sabido, después de determinar en su artículo 137 que «el Estado se organiza territorialmente en municipios, provincias y en las Comunidades autónomas que se constituyan", les reconoce a todas ellas «autonomía para la gestión de sus respectivos intereses", lo que para las entidades locales aparece especificando en

\footnotetext{
2 Sobre el sentido anfibológico del término Estado vid. M. ARAGON REYES, «El tratamiento constitucional de la autonomía local" en Organización Territorial del Estado (Administración local I), Madrid 1985, pág. 481. La doctrina del Tribunal constitucional ha reconocido la distinta significación entre Estado-comunidad o Estado-ordenamiento y Estado-organización en diferentes sentencias; entre otras, las de 28 de julio de 1981, 5 de agosto de 1983, 7 de junio de 1984 y 30 de enero de 1985.
} 
POTESTAD ORGANIZATORIA Y AUTONOMIA LOCAL

los artículos 140 y 141 del texto constitucional 3 . Y dentro de ella, como contenido mínimo y obligado, es preciso situar la potestad de auto-organización cualquiera que sea el sentido y alcance que se quiera dar a la autonomía local que, ciertamente, presenta unos perfiles de difícil definición como el propio Tribunal Constitucional se encargó de reconocer en su primera Sentencia de 2 de febrero de 1981, recaída en el recurso de inconstitucionalidad sobrevenida de determinados preceptos de la ley de Régimen local de $1955^{4}$; idea que igualmente destaca la Exposición de Motivos de la LBRL aludiendo a "la indeterminación y ambigüedad del concepto".

Adelantaremos, también, que sobre ello hay una inicial unanimidad por parte de la doctrina. Así, Martín Mateo mantiene que «aunque puedan surgir dudas que sólo la ley puede solventar, especialmente en la zona fronteriza sobre el ámbito especifico de lo que sean los intereses locales autogestionables, parece imposible concebir un régimen autónomo que merezca tal calificación sin reconocer a la comunidad o comunidades implicadas la posibilidad de montar las bases de su administración. La auto-organización constituye, a nuestro juicio, no solo un prius, sino, a la par, un atributo lógico del propio concepto de autonomía" 5 .

Fernández Farreres 6 considera que "en cualquier caso... la garantía constitucional de la autonomía local... conlleva, cuando menos, el reconocimiento de la potestad de auto-organización de las entidades locales correspondientes». Añadiendo, seguidamente, que "la auto-organización se presenta... como un aspecto consustancial a la autonomía, es decir, como una materia típica que necesariamente queda remitida al ámbito de las decisiones propias y autónomas de las entidades locales" 7. También

\footnotetext{
${ }^{3}$ Cfr. F. SOSA WAGNER, Manual de Derecho local (Madrid 1987) págs. 55 y ss. y «La autonomía municipal», en Rev. de Administración Pública n. ${ }^{\circ} 100-102$ III, págs 2239 y ss; A. FANLO LORAS, "Fundamentos constitucionales de la Administración local» (Madrid, 1990), págs 233 ss.

${ }^{4}$ Una exposición sistematizada de la doctrina jurisprudencial constitucional sobre el régimen local en M.M. RAZQUIN LIZARRAGA, "Tribunal constitucional y entes locales. La jurisprudencia constitucional sobre el régimen local», en Rev. de Administración Pública n. ${ }^{\circ} 122$, págs. 259 ss.

${ }^{5}$ R. MARTIN MATEO, "El Gobierno municipal», en Rev. de Estudios de la Vida Local n. ${ }^{\circ}$ 227, pág. 425.

6 G. FERNANDEZ FARRERES, «La potestad local de auto-organización. Contenido y límites", en Tratado de Derecho municipal I (Madrid, 1988), pág. 738.

${ }^{7}$ Análoga postura puede verse en V. DE LA VALLINA ", Consideraciones sobre la autonomía local en el Estado autonómicon en Rev. de Estudios de la Vida Local n ${ }^{\circ}$ 213, pág. 48; L. PAREJO, "Garantía institucional y autonomías locales" (Madrid, 1981) pág. 154 y S. MUÑOZ MACHADO, «Derecho público de las Comunidades autónomas II" (Madrid, 1984) pág. 184.
} 
la doctrina italiana 8 y alemana participa de tal posicionamiento;en esta última resulta expresiva la postura de Gönneenwein ${ }^{9}$ quien comienza el estudio de la organización municipal afirmando que «un desarrollo lógico de la autonomía debiera conducir a la conclusión de que es el municipio mismo quien debiera darse su propia constitución interna».

En todo caso, para precisar el sentido, contenido, alcance y límites de tal potestad será necesario tener en cuenta los perfiles que presenta la autonomía local en nuestro ordenamiento jurídico y sobre todo los poderes o competencias que sobre el régimen local correspondan al Estado y a las Comunidades autónomas.

\section{LA AUTONOMIA LOCAL EN LA CONSTITUCION ESPAÑOLA DE 1978.}

La autonomía local tal como aparece configurada en la norma constitucional tiene, ciertamente, sus propias características y exigencias. Y ello por cuanto que la autonomía como concepto jurídico-técnico ha de responder a las exigencias singulares del ente al que se aplica, de lo que se deduce que resultará inútil el intento de elaborar dogmáticamente una formulación de validez general aplicable a las distintas instituciones autónomas que puedan ser reconocidas por el ordenamiento jurídico.

En cualquier caso y a los efectos de esta exposición no es necesario entrar en el análisis pormenorizado de sus exigencias y características. Simplemente nos será de utilidad, para encuadrar y enjuiciar la cuestión de que se trata, retener las siguientes consideraciones.

A) La Constitución no ha establecido un modelo cerrado de autonomía local. Su conceptuación concreta la ha remitido al legislador básico. En defecto de mayor concreción por parte de la ley fundamental el concepto ha sido precisado por la doctrina del Tribunal Constitucional desde la temprana Sentencia, ya mencionada, de 2 de febrero de 1981 hasta la reciente de 21 de diciembre de 1989 referida a la LBRL, pasando, entre otras, por las importantes sentencias de 28 de

\footnotetext{
8 Asi, C. MORTATI, "Instituzioni di Diritto pubblico" (Padua 1958) pág. 578; F. STADERINI, «Principi de Diritto degli enti locali» (Padua 1978); M.S. GIANNINI, "Autonomia pubblica», en Enciclopedie di Diritto IV (Milán 1959) y "Autonomia (saggio sui concetto di autonomia)" en Riv. Trimestrale de Diritto pubblico 1951-I págs. 851 s.s.
}

9 O. GÖNNENWEIN, «Derecho municipal alemán», tr. esp. (Madrid, 1967) pág. 315. 
POTESTAD ORGANIZATORIA Y AUTONOMIA LOCAL

julio de 1981 relativa a las Diputaciones catalanas, la de 23 de diciembre de 1982 recaída en el recurso de inconstitucionalidad promovido por el Parlamento de Cataluña contra determinados contenidos de la ley de Presupuestos Generales del Estado para 1982, la de 27 de febrero de 1987 referente a las Diputaciones valencianas y la de 22 de julio de 1988 que falló el recurso de inconstitucionalidad contra la ley de la Comunidad autónoma de Aragón que aprobó las normas reguladoras del Justicia 10.

B) Como ha precisado el Tribunal Constitucional la autonomía local es un "concepto jurídico indeterminado que ofrece un margen de apreciación muy amplio" (Sentencia de 2 de febrero de 1981), lo que la hace de difícil delimitación apriorística a pesar de los esfuerzos del intérprete constitucional, para quedar remitida —como ya quedó indicado- a la legislación ordinaria sin mayores criterios y principios orientadores y sin más límites que "el del reducto indispensable o núcleo esencial de la institución" (S.T.C. de 28.7.1981, Fundamento Jurídico 3). Ello entraña una indudable fragilidad de la autonomía local 11 , tanto frente al Estado como frente a otros poderes territoriales en el supuesto del Estado compuesto. Así sucede, en efecto, en nuestro Estado de las autonomías. No es preciso recordar cómo la preocupación que los constituyentes demostraron por dar un destacado papel a las Comunidades autónomas en la distribución territorial del poder y en la propia configuración del Estado-comunidad, hace que la Administración local pase a ocupar un lugar secundario dentro de las instituciones político-administrativas. Incluso, inicialmente, el anteproyecto de Constitución, tal como apareció en el Boletín de las Cortes, incluía a la Administración local en el Título $\mathrm{V}$ del Gobierno y de la Administración, en un claro intento de minusvalorar la significación constitucional de las Entidades locales 12. Con buen criterio al final se incorporó al Título VIII De la organización Territorial del Estado, ya que se entendió que la problemática del régimen local no debe separase del tema regional y en todo caso es una pieza básica de la organización del Estado-ordenamiento, como los ejemplos

\footnotetext{
10 Una exposición de los primeros pronunciamientos del Tribunal Constitucional sobre la autonomía local en P. ESCRIBANO COLLADO «La autonomía local en la jurisprudencia del Tribunal Constitucional", en Estudios Homenaje a C. Ruiz del Castillo (Madrid 1985) págs. 115 ss.

11 Vid F. LEVI, «Los entes locales territoriales», en La Costituzione spagnola 1978, pág. 131.

12 Cfr. S. MARTIN-RETORTILLO, "Las Comunidades locales en el anteproyecto de Constitución", en Rev. de Estudios de la Vida Local n 197, págs. 9 ss.
} 
comparados de Estado-compuesto ponen de manifiesto y acredita el propio precedente español de la Constitución de $1931{ }^{13}$.

C) Los «poderes autónomos se circunscriben a la gestión de sus respectivos intereses, lo que exige que se dote a cada ente de todas las competencias propias y exclusivas que sean necesarias para satisfacer el interés respectivo" (S.T.C. 2 de febrero 1981 y 28 de julio de 1981).

D) La autonomía hace referencia a un poder por esencia limitado. En efecto, la autonomía no equivale a soberanía y «aun este poder tiene limites y dado que cada organización territorial dotada de autonomía es una parte del todo, en ningún caso el principio de autonomía puede oponerse al de unidad, sino que es precisamente dentro de éste donde alcanza su verdadero sentido, como expresa el artículo 2 de la Constitución" (S.T.C. de 2 de febrero de 1981, Fundamento Jurídico 3).

Estos límites, en el caso de la autonomía local, pueden venir establecidos tanto por parte del Estado como por las Comunidades autónomas ${ }^{14}$, en virtud del ejercicio de las competencias que constitucionalmente puedan corresponderles sobre el régimen local. Es decir, esos límites podrán estar fijados por la ley general o por la ley territorial, utilizando expresiones que se contienen en la Exposición de Motivos de la ley $7 / 85$, de 2 de abril.

Por ello, antes de seguir adelante será de interés precisar los términos en que se efectúa la distribución constitucional de competencias sobre la Administración local.

\section{LA DISTRIBUCION DE COMPETENCIAS ENTRE EL ESTA- DO Y LAS COMUNIDADES AUTONOMAS EN MATERIA DE RÉGIMEN LOCAL: EL CARACTER BIFRONTE DEL REGI- MEN LOCAL}

La existencia de un Estado compuesto como nuestro Estado de las autonomías plantea la gran cuestión de determinar el poder territorial al

\footnotetext{
13 Sobre la ubicación de la Administración local en el texto constitucional de 1978 y las consecuencias que de ello se siguen, vid. J.L. MEILAN GIL, "La articulación de los ordenamientos local y autonómicos», en Rev. Española de Derecho administrativo n ${ }^{\circ} 44$, págs. 666-667.

14 Es la lógica consecuencia de la «distribución vertical del poder público entre entidades de distinto nivel" y de la autonomía puramente administrativa de los entes locales frente a la autonomía política que caracteriza a las Comunidades autónomas, de que habla el Tribunal Constitucional (S.T.C. de 28 de julio de 1981, Fundamento Jurídico 3), aunque ello
} 
POTESTAD ORGANIZATORIA Y AUTONOMIA LOCAL

que corresponda la competencia para la regulación del régimen local. Se trata, ciertamente, como dice Guaita de uno de los asuntos «más tentadores para las nuevas autonomías territoriales" 15 . Por ello no es extraño que desde el principio de los debates constitucionales quedase planteada la cuestión con una evidente carga política y que las tensiones y puntos de vista encontrados tengan su lógico reflejo en la redacción definitiva del texto constitucional. La situación se resolvió con un intencionado silencio de la Constitución. No existe una atribución expresa de la competencia sobre la legislación de régimen local en el texto constitucional. Unicamente el artículo 148.1 .2 se refiere a la legislación de régimen local al permitir que las Comunidades autónomas puedan asumir las funciones que correspondan a la Administración del Estado y cuya transferencia autorice dicha legislación de régimen local; precepto en el que algún autor quiere ver un inequívoco título competencial en favor del Estado ${ }^{16}$ lo que ha hecho que haya sido valorada esa "alusión a una legislación de régimen local» como una declaración donde «existe latente un resabio de arrinconar cualquier atisbo de orden federalista" 17.

Sin duda, algún sector de los constituyentes quisieron aplicar en este caso el precedente de 1931. En efecto, la Constitución de la II República no atribuía la competencia sobre la Administración local ni al Estado ni a las Regiones, por lo que podía llegar a ser asumida por éstas últimas plenamente, por medio de sus respectivos Estatutos. Esta es, precisamente, también la formula de la Ley Fundamental de Bonn que guarda silencio en este punto lo que ha permitido, en virtud del juego de la cláusula residual, otorgar a los Länder la titularidad de la competencia sobre las entidades locales 18 .

no quiera decir que la autonomía local no presente una relevancia y significación política evidente (Cfr. M. ARAGON, «El tratamiento constitucional...», op. cit. pág. 468).

15 A. GUAITA, "Competencias del Estado y de las Comunidades autónomas en materia de Administración local", en Estudios Homenaje a C. RUIZ del CASTILLO, Madrid 1985, pág. 264.

16 Cfr. S. MARTIN-RETORTILLO, "La actuación de las Corporaciones locales. Acotaciones al proyecto de ley de regulación de las bases de régimen local», en Estudios Homenaje a C. RUIZ DEL CASTILLO, op. cit. pág. 365).

17 Vid. J.M. CASTELLS, "El municipio en la autonomía política», en Documentación administrativa n. ${ }^{\circ} 182$, pág. 483.

18 Cfr. S. MUÑOZ MACHADO, Derecho público de las Comunidades autónomas II, op. cit. págs. 185-86). 
Este vacio constitucional, claramente intencionada, queda sin embargo cubierto por la cláusula competencial que otorga al Estado el artículo 149.1.18 para regular «las bases del régimen jurídico de las Administraciones públicas.... que en todo caso garantizarán a los administrados un tratamiento común ante ellas", así como por la garantía constitucional de la propia autonomía local. No sin cierta resistencia ${ }^{19}$, ya que la carga política que encierra la cuestión no facilita su pacífica comprensión y aceptación, fue abriéndose camino la tesis de que dicha previsión constitucional habilitaba al Estado para llevar a efecto la ordenación del régimen local, sin perjuicio de la competencia que sobre ese ámbito pueda corresponder a las Comunidades autónomas de conformidad a sus respectivos Estatutos; de esta forma no se hizo realidad la intención de poder atribuir a las Comunidades autónomas de forma plena la competencia sobre el régimen local.

Partiendo de dicha interpretación que fue implícitamente compartida por el Tribunal Constitucional, inicialmente en su Sentencia de 2 de febrero de 1981 y de manera definitiva y expresa a partir de las Sentencias de 28 de julio de 1981 y 5 de agosto de 1983, dispone el Estado de competencia para la regulación de las bases del régimen local cuya ejecución y desarrollo normativo puede ser asumido por las Comunidades autónomas en sus respectivos Estatutos. Bien entendido que la competencia autonómica de conformidad a la Constitución (arts. 148 y 149) sólo podrá ser recogida por los Estatutos de aquellas Comunidades mayores o "con mayor nivel de autonomía", según la expresión reiteradamente utilizada por el Tribunal Constitucional (S.T.C. 5 de agosto de 1983); es decir, sólo podrán disponer de esta competencia normativa, que no es puramente reglamentaria según ha precisado también el Tribunal Constitucional (S.S. de 28 de julio de 1981, Fundamento Jurídico 5 y 27 de febrero de 1987, Fundamento Jurídico 3), las Comunidades autónomas históricas (Disposición Transitoria Segunda de la C.E.), las que accedieron a la autonomía por el procedimiento del artículo 151 de la Constitución, así como Canarias y Valencia en virtud del aumento del techo competencial producido por las leyes orgánicas $11 / 82$ y 12/82, de 10 de agosto y la Comunidad foral de Navarra según reconoce su régimen paccionado recogido en la ley orgánica $13 / 82$, de 10 de agosto. Las restantes Comunidades autónomas sólo disponen de las competencias a que se refiere el artículo 148.1.2. (alteración de términos municipales y en general aquellas funciones propias de la Administración del Estado cuya transferencia autorice la legislación de régimen local), que al tratarse de "funciones que correspondan a la Administración del Estado" en

19 Cfr J.M. CASTELLS, «El municipio en la autonomía política», op. cit. pág. 483. 
POTESTAD ORGANIZATORIA Y AUTONOMIA LOCAL

ningún caso puede entenderse que den lugar a la asunción de competencias legislativas, al margen de aquéllas referentes a la estricta alteración de términos municipales.

Esta competencia del Estado para regular la ordenación del régimen local encuentra su apoyatura jurídica no sólo en el ya mencionado artículo 149.1.18 de la Constitución, sino y sobre todo, como se dice en la Sentencia del Tribunal Constitucional de 28 de julio de 1981 y reitera la más reciente de 21 de diciembre de 1989, en el hecho de que la "garantía constitucional es de carácter general y configuradora de un modelo de Estado, y ello conduce, como consecuencia obligada, a entender que corresponde al mismo la fijación de los principio o criterios básicos en materia de organización y competencias».

Así, pues, como ha precisado el Tribunal Constitucional en su Sentencia de 23 de diciembre de 1982, es indudable el «el carácter bifronte del régimen jurídico de las autonomías locales", partiendo del hecho de que los Estatutos de autonomía han asumido como competencia exclusiva el régimen local sin perjuicio de lo que dispone el artículo 149.1.18 de la Constitución, tal como establecen, por ejemplo, el artículo 9.8 del Estatuto de Cataluña o el artículo 31.8 del Estatuto de la Comunidad Valenciana. La conclusión es, por tanto, que aun respetando la competencia autonómica, dado el alcance que ha de darse a la expresión "régimen jurídico de las Administraciones públicas" - tal como fué precisado por el Tribunal Constitucional en sus Sentencias de 28 de julio de 1981 (Fundamento Jurídico 5) y 5 de agosto de 1983 (Fundamento Jurídico 38) - resulta indudable la competencia básica del Estado para la regulación general del régimen local.

Por consiguiente, al régimen local resulta imposible calificarlo de forma unívoca como intracomunitario o extracomunitario (S.T.C. 23 de diciembre de 1982), ya que gozará de ambos caracteres a la vista del bloque de la constitucionalidad. La regulación institucional básica corresponderá al Estado ${ }^{20}$ y la funcional o competencial al Estado y a las Comunidades autónomas, según su respectivo orden de atribuciones. A ello se llega teniendo presente que el régimen local no es una mera materia o actividad concreta del poder como tantas otras de las enumeradas en los diferentes apartados del artículo 149 de la Constitución. El régimen local, como las demás cuestiones que se contienen en el apartado 18 de dicho precepto constitucional, hace referencia a una "acción, por así decir, reflexiva del Estado, esto es, a la que él mismo lle-

20 Cfr. R. GOMEZ-FERRER, «Legislación básica en materia de régimen local. Relación con las leyes de las Comunidades autónomas" en La provincia en el sistema constitucional, Madrid 1991, págs. 47 ss. 
va a cabo en relación al aparato administrativo que constituye su instrumento normal de actuación» (S.T.C. de 28 de julio de 1981) ${ }^{21}$.

\section{LA CONFIGURACION DE LA POTESTAD ORGANIZATORIA DE LOS ENTES LOCALES EN EL ORDENAMIENTO JURIDI- CO ESPAÑOL}

\subsection{Delimitación previa}

Se está ya en condiciones de seguir adelante en la configuración de la potestad organizativa de los entes locales, con dos precisiones que estimo necesario efectuar.

Por un lado, que se trata de estudiar la cuestión en relación a las entidades locales que gozan de efectiva autonomía constitucionalmente garantizada, es decir, respecto de las entidades locales de existencia necesaria, en cuanto que están expresamente reconocidas en la Constitución. Son las entidades locales que, con terminología no muy afortunada el texto legal de bases de régimen local (LBRL) califica como entidades territoriales, es decir, el municipio, la provincia y la entidad insular. La distinción entre estas entidades de existencia necesaria y el resto de las entidades locales de existencia facultativa no hay que verla, simplemente, en el reconocimiento de una serie de potestades o poderes jurídicos, tales como los que se enumeran en el artículo 4.1 de la ley $7 / 85$, entre las que se encuentra precisamente la potestad de auto-organización, sino en el grado en que se produce el reconocimiento y garantía de la autonomía del ente. Las entidades locales de existencia necesaria tienen reconocida su autonomía a nivel constitucional (artículos 140-141 de la Constitución y artículos 1 y 2 de la LBRL), mientras que el resto de las entidades locales tendrán, en su caso, reconocida su autonomía, con los poderes jurídicos que se estimen pertinentes, por medio de las leyes de la correspondiente Comunidad autónoma (artículos 4.2 y ss. de la LBRL).

Los poderes o potestades son simple consecuencia de la autonomía cuya causa -que en definitiva es lo que importa- hay que encontrarla en el grado en que se produce el reconocimiento y garantía de la misma: la Constitución en un caso, la ley territorial o autonómica en el otro ${ }^{22}$. Este posible doble fundamento de la autonomía local (constitucional o legal),

21 Sobre esta forma de entender el régimen local en cuanto ámbito competencial vid. S. MUÑOZ MACHADO, Derecho público de las Comunidades autónomas II, op. cit. págs. 183 ss.

22 Cfr. L. MORELL OCAÑA, El régimen local español I (Madrid 1988), pág. 32. 
POTESTAD ORGANIZATORIA Y AUTONOMIA LOCAL

está recogido en el artículo 2 de la Carta Europea de Autonomía Local y en nuestro ordenamiento jurídico el reconocimiento de las entidades locales de existencia facultativa, como ha quedado indicado, queda remitido a la normativa autonómica (arts. 42 ss. y Disposición Transitoria Primera de la LBRL), ya que como tiene declarado el Tribunal Constitucional, en su Sentencia de 21 de diciembre de 1989 «su propia existencia (entra) en el ámbito de disponibilidad de las Comunidades autónomas que dispongan de la correspondiente competencia" (Fundamento Jurídico 4).

En cualquier caso, queda confirmado el principio que dejamos inicialmente establecido de interrelación entre autonomía y potestad de organización, ya que sólo las entidades locales cuya autonomía se encuentre constitucionalmente garantizada tendrán necesariamente reconocida una potestad de auto-organización.

En segundo término, conviene asimismo tener presente que la potestad auto-organizatoria hace referencia a ámbitos más amplio que los estrictamente organizativos; no se circunscribe, únicamente a las cuestiones relativas a los órganos de gobierno y administración, sino que alcanza también a los aspectos referentes al funcionamiento de la entidad. Como señala Fernández Farreres 23 «libertad de organización y libertad de funcionamiento constituyen las dos manifestaciones en que substancialmente se resume la capacidad de auto-organización". Bien entendido, que tan sólo el examen del primer aspecto nos interesaría los efectos de este estudio.

\subsection{Principios constitucionales en relación al gobierno local}

La configuración de la potestad organizatoria local es preciso enmarcarla partiendo de los principios o criterios que al respecto se establecen en la Constitución. Son las que califica de "predeterminaciones orgánicas" Mercadal Vidal 24.

En la historia de nuestro constitucionalismo siempre la norma suprema estableció determinados criterios acerca del gobierno local y así lo hace también la Constitución vigente, efectuando los pronunciamientos siguientes, que a nivel de regulación constitucional pueden considerarse suficientes:

23 G. FERNANDEZ FARRERES, La potestad local de auto-organización, pág. 739.

${ }^{24}$ F. MERCADAL VIDAL, "Organización municipal" en Tratado de Derecho municipal I (Madrid, 1988) pág. 873. 
a) Municipios y provincias gozan de personalidad jurídica.

b) El gobierno y administración municipal corresponde al Ayuntamiento integrado por el Alcalde y concejales. Los concejales serán elegidos por los vecinos del municipio mediante sufragio universal, igual, libre, directo y secreto. La elección del Alcalde permite una doble opción constitucional: elección por los concejales o directamente por los vecinos.

c) Se reconoce la posibilidad constitucional del modelo de gobierno asambleario en régimen de Concejo abierto.

d) El gobierno y administración de la provincia en cuanto entidad local se encomienda a la Diputación u otras corporaciones de carácter representativo, sin precisar el sistema de elección. Las islas de los archipiélagos tienen su propio gobierno y administración en forma de Cabildos o Consejos 25.

A dichos principio constitucionales, expresamente referidos al modelo de gobierno local, habría que añadir los principios organizativos que se contienen en el artículo 103 de la Constitución y cuya aplicación a todas las Administraciones públicas puede estimarse se encuentra admitida legal 26 , doctrinal 27 y jurisprudencialmente 28 , al menos con carácter de principio o directiva constitucional aunque su operatividad y eficacia varíe, obviamente, en cada entidad administrativa en función de su naturaleza y peculiaridades.

25 Este modelo es la consecuencia de las peculiares características que presentan las entidades locales en cuanto Administraciones públicas, donde no tiene lugar la separación entre representación y administración, sino una total y plena identificación; cfr. al respecto L. MORELL, La Administración local (Madrid 1984) pág. 47.

26 Muchos Estatutos de Autonomía han incorporado expresamente estos principios organizativos, asi como la propia LBRL (art. 6.1) y las leyes autonómicas de régimen local.

27 Salvo excepciones, (así J.L. MEILAN, «La articulación de los ordenamientos local y autonómico», op. cit. págs. 667-668, que entiende que el Título IV de la Constitución «está primariamente pensado para la Administración del Estado" y M. BAENA, Organización administrativa, Madrid 1984, págs. 69-70), la doctrina en general admite la aplicación de los principios organizativos contenidos en el artículo 103 de la Constitución a todas las Administraciones públicas; vid, por todos R. ENTRENA CUESTA, La Administración local en la Constitución de 1978 (CEC. Madrid 1980) pág. 121.

28 Vid. Sentencias del Tribunal Constitucional de 28 de julio 1981, 22 de febrero de 1982, 27 de julio de 1982, 5 de agosto de 1983 y 27 de febrero de 1987. 
POTESTAD ORGANIZATORIA Y AUTONOMIA LOCAL

\subsection{El desarrollo de los principios constitucionales}

El texto constitucional se limita a establecer - como acabamos de ver-los principios propios de un sistema democrático de gobierno local en la línea que viene reconocida en el artículo 3 de la Carta Europea de Autonomía local y que, por otra parte, es la propia de nuestra historia constitucional ${ }^{29}$. Partiendo de tales principio, como es evidente, caben formulaciones organizativas de detalle diversas 30; opciones en las que se concreta la organización propia del gobierno y administración de las entidades locales y cuya decisión, en un planteamiento abstracto, puede corresponder a la propia entidad en cuanto manifestación plena de auto-gobierno o a otra instancia superior, que en nuestro ordenamiento jurídico puede ser la Comunidad autónoma o el Estado.

La primera de las opciones, que inicialmente pudiera aparecer como la más consecuente y conforme a las exigencias de un auténtico auto-gobierno local, es un desiderátum que en la práctica no resulta razonable ni posible, como lo prueba que ningún ordenamiento jurídica la tenga reconocida. Ello es así, dado que las entidades locales son parte de un todo, piezas básicas de estructuración de la entera organización territorial política -el escalón primero, si se quiere-, como se desprende de nuestra Constitución y tiene reconocido la jurisprudencia constitucional. Es decir, se trata de una pieza de un complejo aparato político que necesariamente ha de actuar bajo pautas unitarias, de donde se deducen los límites que la autonomía lleva consigo, tal como se vio.

Queda por consiguiente la opción de otorgar la competencia al Estado o a las Comunidades autónomas para establecer, en desarrollo de la Constitución, los principios o criterios propios de una estructura de gobierno y administración común y básica para las entidades locales. Y es aquí donde el derecho comparado ofrece en el Estado compuesto formulas diversas. Los Estados federales tienden a encomendar tal competencia a los Estados miembros, tal como sucede en la Alemania Federal con los Länder y en Estados Unidos en que la competencia sobre la Administración local corresponde a los Estados de la Unión. La Constitución española en este punto, como en general sucede con todo el régimen local según vimos, guarda silencio, lo que ha motivado la tensión a que se ha hecho referencia entre el Estado y las Comunidades autónomas para

29 Sobre antecedentes históricos de la organización local en el Derecho español, Vid. L. COSCULLUELA, «Organización y régimen jurídico de las entidades locales», en Organización Territorial del Estado (Administración local I (Madrid 1985) págs. 121-129.

30 Sobre los diversos modelos de gobierno local vid. R. MARTIN MATEO, «El Gobierno municipal» op. cit., págs. 414 ss. 
hacerse con la competencia sobre la Administración local y que se ha decantado, con carácter general, en favor del Estado ${ }^{31}$. Expresiva en tal sentido resulta la Sentencia del Tribunal Constitucional de 28 de julio de 1981 al declarar expresamente que:

«Las comunidades locales no pueden ser dejadas en lo que toca a la... configuración de sus órganos de gobierno a la interpretación que cada Comunidad autónoma pueda hacer de ese derecho a la autonomía constitucionalmente garantizada... La garantía constitucional es de carácter general y configuradora de un modelo de Estado y ello conduce como consecuencia obligada a entender que corresponde al mismo la fijación de principios o criterios básicos en materia de organización y competencias de aplicación general en todo el Estado».

Doctrina que es reiterada en posteriores Sentencias del Tribunal Constitucional y expresamente recogida en la Sentencia de 21 de diciembre de 1989 (Fundamento jurídico 1).

Este mismo fundamento es el que sirve de justificación a la LBRL al decir en su Exposición de Motivos que "se está, en definitiva, ante una ley que atañe a la construcción misma del Estado y al diseño de uno de los ordenamientos jurídico-administrativos que en él se integran".

Ello, sin embargo, no quiere decir que las Comunidades autónomas hayan quedado desposeídas de competencias en este ámbito. El carácter bifronte del régimen local, según la expresión del Tribunal Constitucional, es evidente en nuestro ordenamiento jurídico, de forma tal que ninguna de las dos instancias puede monopolizar el tratamiento de las cuestiones organizativas 32; que esto sea así, es la consecuencia obligada del carácter que presentan las entidades locales y especialmente el municipio: pieza integrante de la organización del Estado, pero al mismo tiempo elemento o componente de la estructura de la

31 En relación a los aspectos estrictamente organizativos no falten autores que se inclinan por considerar que deben ser de la competencia exclusiva de las Comunidades autónomas "por afectar a sus instituciones de auto-gobierno»; así M. BAENA, Organización administrativa, op. cit. pág. 70, a quien sigue en este punto J.L. MEILAN GIL, "La articulación de los ordenamientos local y autonómico», op. cit. pág. 669. Es, asimismo, la tesis mantenida por la Generalidad de Cataluña como actora de la impugnación del artículo 28 de la ley de Presupuestos Generales del Estado para 1982 (S.T.C. 23 de diciembre de 1982): «Las Corporaciones locales como integrantes de la organización territorial catalana" y que, como es sabido, no es compartida por el Tribunal Constitucional que defiende el carácter bifronte del régimen local.

32 Sobre la cuestión, vid. S. MUÑOZ MACHADO, Derecho público de las Comunidades autónomas, op. cit. págs. 187-193. 
POTESTAD ORGANIZATORIA Y AUTONOMIA LOCAL

respectiva Comunidad autónoma, lo que explica que toda autonomía tenga límites.

\subsection{La potestad organizatoria en la LBRL}

Por consiguiente, sin perjuicio de que las Comunidades autónomas al menos las de primer grado o "con mayor nivel de autonomía»- tengan competencia sobre las cuestiones organizativas de las entidades locales que se incluyan en su territorio, la competencia primera o básica corresponde al Estado aunque, obviamente, no pueda agotar la materia no solo por respeto a la potestad de auto-organización de la entidad local, sino también dada la competencia de las Comunidades autónomas, que en principio no cabe desconocer.

En definitiva, se trata de precisar la cuestión siempre difícil y delicada de lo que debe entenderse por básico; hasta qué suerte de detalle, hasta qué grado de profundización, puede llegar la regulación básica que corresponde al Estado. Cuestión que, como es bien sabido, no resulta posible determinar de forma apriorística y general tal como tiene reconocido el Tribunal Constitucional, entre otras, en su Sentencia de 28 de julio de 1981, precisamente en relación a la legislación básica de régimen local:

"Ciertamente no será siempre fácil la determinación de qué es lo que haya de entenderse por regulación de las condiciones básicas o establecimiento de las bases de régimen jurídico y parece imposible la definición precisa y apriorística de este concepto. Las Cortes deberán establecer qué es lo que haya de entenderse por básico y en caso necesario será este Tribunal el competente para decidirlo, en su calidad de intérprete supremo de la Constitución (art. 1 Ley orgánica del Tribunal Constitucional)» (Fundamento Jurídico 5).

La LBRL en su Exposición de Motivos, al referirse a la regulación que establece, expresamente se pronuncia por «la constricción del marco general a lo estrictamente indispensable para satisfacer el interés general» y más adelante -en relación a la organización interna de las entidades locales- expresamente se pronuncia por «reconocer la supremacía» del interés de las propias entidades sobre el interés autonómico, con las consecuencias que luego se verán.

El Estado haciendo uso de esa competencia o mandato implícito de la Constitución (este es el término que utiliza la Sentencia del Tribunal Constitucional de 2 de febrero de 1981), es decir, asumiendo el título competencial que le atribuye el artículo 149.1.18 del texto constitucional 
en los términos fijados por el Tribunal constitucional (S.T.C. 2 de febrero de 1981, 28 de julio de 1981 y 5 de agosto de 1983), ha promulgado la ley 7/1985, de 2 de abril, reguladora las bases de régimen local (LBRL) que expresamente invoca en su Exposición de Motivos dicho precepto constitucional como título competencial para su aprobación.

Se trata de una norma básica con el significado y alcance que el término presenta dentro del sistema plural de fuentes normativas establecido en nuestra Constitución 33 y que da lugar — como es bien sabido- a una amplia tipología de leyes.

El concepto de normativa básica constituye una de las categorías jurídicas más imprecisas que se derivan de nuestra Constitución 34 , sobre la que el Tribunal Constitucional ha tenido que formular amplios y diversos pronunciamientos a partir de la Sentencia de 28 de julio de 1981 y sin que pueda afirmarse que haya llegado a una formulación definitiva y precisa. Son productos normativos que hacen referencia a la competencia del Estado en un ámbito compartido con las Comunidades autónomas, de forma tal que la norma básica venga a establecer los principios o criterios generales que en desarrollo de la Constitución han de presidir la regulación de un sector o ámbito del ordenamiento jurídico o de una materia que deba ser común a todo el Estado, así como precisar los límites dentro de los que ha de desenvolverse la potestad normativa autonómica. Se trata de normas directamente vinculadas a la Constitución, es decir, normas primarias o actos normativos primarios tal como en relación a la ley de Régimen local específicamente sostiene el Tribunal Constitucional en su Sentencia de 8 de julio de 1988. En cierta forma podrían incluirse dentro de la tipología normativa de ley cabecera de grupo normativo formulada por Villar Palasi 35.

33 Cfr. R. GOMEZ-FERRER, "Legislación básica en materia de régimen local; relación con las leyes de las Comunidades autónomas" en La provincia en el sistema constitucional (Madrid 1991) págs. 57 ss.

$34 \mathrm{Cfr}$. A. BAYONA, «La evolución del concepto de competencia básica en la doctrina y jurisprudencia constitucional», en Rev. Española de Derecho Administrativo n. ${ }^{\circ} 45$, págs. 55 ss; E. GARCIA DE ENTERRIA, “Ordenamiento estatal y los ordenamientos autonómicos; sistema de relaciones" en Rev de Administración Pública n. ${ }^{\circ} 100-102$ I, págs. 231 ss.; J.M. LOPEZ BENITEZ "Doctrina del Tribunal Constitucional sobre las leyes básicas», en Rev de Estudios de Administración Local y Autonómica n. ${ }^{\circ} 235-36$, págs. 537 ss.

35 J.L. VILLAR PALASI, «La interpretación y los apotegmas jurídico-lógicos a la luz del nuevo título preliminar del Código civil desde una perspectiva teórica» (Madrid 1975); Apuntes de Derecho administrativo I (Madrid 1977); después de la Constitución de 1978 VILLAR PALASI utiliza la categoría de los bloques y grupos normativos en su estudio sobre "Potestad normativa de la Comunidad de Madrid", en Estudios sobre el Derecho de la Comunidad de Madrid (Madrid 1987) págs. 221 y ss. En análogo sentido F. GONZALEZ NAVARRO, Derecho administrativo español I (Pamplona 1987) págs. 243 ss y R. GOMEZFERRER. "Legislación básica en materia de régimen local...», op. cit., pág. 50. 
POTESTAD ORGANIZATORIA Y AUTONOMIA LOCAL

Partiendo de esta noción de ley básica — que es instrumento normativo clave del Estado autonímico- es como hay que valorar la ley reguladora de las bases de Régimen local, tal como ha hecho el Tribunal Constitucional en su Sentencia de 27 de febrero de 1987 y sobre todo en la de 21 de diciembre de 1989 que directamente se pronuncia sobre la constitucionalidad de la LBRL.

Antes de seguir adelante, es de indicar que la LBRL en lo que se refiere a los órganos de gobierno local, deja al margen el sistema representativo, sin entrar a regular la cuestión, que queda remitida a la ley Electoral General (Título II, arts. 176 a 209 de la ley orgánica 5/85, de 19 de junio), de conformidad al criterio mantenido por el Tribunal Constitucional en su Sentencia de 16 de Mayo de 1983, que resolvió el recurso de inconstitucionalidad contra la modificación de determinados artículos de la anterior ley de Elecciones locales de 17 de julio de 1978.

Por lo que se refiere a la estructura orgánica de las entidades locales la LBRL distingue, como resulta pertinente, entre entidades de existencia necesaria y de constitución voluntaria o facultativa. Las líneas fundamentales o básicas de la organización propia de las primeras vienen establecidas directamente por la LBRL, distinguiendo una organización preceptiva y órganos complementarios, tanto para municipios como provincias (arts. 20 y 32 LBRL). Los órganos preceptivos de general y uniforme aplicación -salvo lo referente a la organización provincial del País Vasco (Disposición Adicional Segunda LBRL) 35 bis y lo que pudiera derivarse de lo establecido en la Disposición Adicional Tercera en relación al régimen local de Navarra 36 - aparecen regulados por la ley básica, en determinados aspectos, con tal detalle que esa regulación puede estimarse, en ocasiones, no solamente poco respetuosa con la autonomía local sino también atentatoria a los principios constitucionales, como sucede con la composición de la Comisión de Gobierno municipal tal como más adelante se precisará.

La regulación de la organización local complementaria es para la LBRL atribución del Reglamento orgánico de cada entidad como manifestación de su potestad auto-organizatoria (art. 4.1. a. de la LBRL y art. 6.1 de la Carta Europea de Autonomía local) "sin otro límite que el

35 bis También, naturalmente quedan exceptuados de la organización prevista en la LBRL los municipios que funcionan en régimen de concejo abierto.

36 Vid. M.M. RAZQUIN, "El régimen especial de Navarra", en Tratado de Derecho municipal I (Madrid 1986) págs. 971 ss. y D. LOPERENA, "Autonomía foral y competencias sobre Administración municipal en Navarra", en Rev. de Estudios en la Vida Local y Autonómica n. ${ }^{\circ} 240$, págs. 1637 y ss. 
respeto a la organización determinada por esta ley» y sin perjuicio de que las leyes de las Comunidades autónomas puedan establecer una organización complementaria que será de aplicación en todo aquello que los Reglamentos orgánicos no dispongan lo contrario (arts. 5.A, 20.2 y 32.2 LBRL). Por consiguiente, el juego de los artículos 5.A, 20.2 y 32.2 de la LBRL hace que la potestad normativa de las Comunidades autónomas en este ámbito organizativo sólo sea de aplicación en el supuesto que la Entidad local no haya aprobado su propio Reglamento orgánico $\mathrm{o}$, al menos, en la medida que resulte compatible con el contenido de éste. Solución, que en principio, se presenta como harto discutible desde el punto de vista constitucional con las consecuencias que luego se indicarán. ${ }^{37}$.

En efecto, con esta configuración de la potestad organizatoria local se produce un desapoderamiento de las competencias de las Comunidades autónomas que puede considerarse contrario al bloque de la constitucionalidad, ya que la legislación autonómica queda relegada al papel de mera norma supletoria en defecto de la potestad normativa de las entidades locales. Es este uno de los motivos de los recursos de inconstitucionalidad formulados contra la ley 7/1985 por el Parlamento y la Generalidad de Cataluña, así como por el Parlamento y la Junta de Galicia y que da lugar a la decisión del Tribunal Constitucional que se recoge en su Sentencia de 21 de diciembre de 1989, a la que me referiré más adelante. ${ }^{38}$.

De conformidad a la Constitución y a los Estatutos de Autonomía, según se ha visto, la competencia básica corresponderá al Estado y su desarrollo a las Comunidades autónomas, al menos a las de primer grado. Por ello, si la solución adoptada por la ley general y básica puede reputarse conforme a las exigencias de la autonomía local, tal como parece justificar la propia Exposición de Motivos de la LBRL, es indudable que surgen dudas razonables acerca de su acomodación a los parámetros constitucionales. A la vista de la regulación que se contiene en

\footnotetext{
37 Por otra parte, en este punto, la Disposición Adicional Primera de la LBRL parece conferir facultad legislativa a todas las Comunidades autónomas sin distinción, sin tener en cuenta que partiendo del marco constitucional las que han accedido a la autonomía por la llamada via lenta no ostentan tal competencia.

38 El motivo de la impugnación en este punto se debe no sólo a que «de un plumazo hace desaparecer la competencia exclusiva de Cataluña sobre Régimen local", sino tam. bién a que se considera infringido el principio de jerarquía normativa (art. 9.3 de la Constitución) dado que "la efectividad de la legislación autonómica queda supeditada a su no oposición a lo que dispongan los respectivos Reglamentos orgánicos de las entidades locales".
} 
POTESTAD ORGANIZATORIA Y AUTONOMIA LOCAL

la LBRL la doctrina se manifestó dividida en este punto ${ }^{39}$. Frente a quien apoyaban y defendían la solución de la ley básica por entender que era la más acorde con el principio de autonomía local, ya que en otro caso podía quedar radicalmente eliminada, no faltaron voces que apuntaban a la inconstitucionalidad de la fórmula utilizada ${ }^{40}$.

Asimismo, tendrá carácter supletorio de segundo grado, en defecto de la normativa autonómica de régimen local, la legislación que el Estado pueda dictar con carácter no básico y que estará constituida por los preceptos de la anterior legislación que no resulten derogados por la ley básica, lo que tendrá lugar en la medida en que no «se opongan, contradigan o resulten incompatibles con las disposiciones de esta ley» (Disposición derogatoria de la LBRL), así como los Reglamentos actualizados a que se refiere la Disposición Final Primera ${ }^{41}$.

39 División y enfrentamiento de pareceres que llega al seno del propio Tribunal Constitucional, como se tendrá ocasión de ver.

40 A favor de la solución de la LBRL, claramente, G. FERNANDEZ FARRERES, «la potestad local de auto-organización», op. cit. págs. 745-746; R. MARTIN MATEO, "El Gobierno municipal», op. cit. pág. 429, que justifica la preeminencia del Reglamento orgánico de la entidad local entendiendo que «en el juego de competencias básicas estatales-competencias autonómicas de desarrollo, el principio constitucional de autonomía funciona independientemente, coartando toda injerencia en la voluntad de los órganos locales que vaya más allá de lo básico, cuya definición corresponde solo al Estado»; A. EMBID IRUJO, "Ordenanzas y Reglamentos municipales», en Tratado de Derecho municipal I (Madrid 1988) págs. 416-418 y F. MERCADAL, "Organización municipal», op. cit. pág. 879 .

En contra, L. COSCULLUELA "Organización y régimen jurídico de las Entidades locales», op. cit. págs. 134 y ss., enjuiciando críticamente el proyecto de la LBRL en este punto, que no sufrió alteración alguna en el texto definitivamente aprobado, que le merece la siguiente valoración: «lo que no puede hacer es desapoderar a las Comunidades de su potestad legislativa de desarrollo en favor de otras entidades de distintas... De ahí que la solución del proyecto sea inconstitucional al degradar el valor normativo de la legislación autonómica que se convierte en supletoria de los Reglamentos locales». En sentido análogo A. BAYONA, «La organización territorial de Cataluña; marco jurídico y propuestas», en Autonomies n. ${ }^{\circ} 5$ (1986) págs. 21 ss.

41 Concretamente, y por lo que se refiere a la cuestión que ahora interesa, en uso del mandato conferido al Gobierno de la Nación por dicha Disposición Final Primera fue aprobado por Real Decreto 2568/86, de 28 de noviembre, el Reglamento de Organización, Fundamiento y Régimen Jurídico de los Entidades locales que contiene, con ese carácter supletorio que quedó indicado, una completa regulación de los aspectos organizativos de las Entidades locales, tanto de los «Organización necesaria de los entes locales territoriales» (Tít. II, arts. 35 a 76), como "De la organización complementaria de los entes locales territoriales» (Tít. IV, arts. 119-133) y "De la organización y funcionamiento de otras Entidades locales" (Tít. V arts. 140-145); sobre el carácter de este Reglamento vid. T. QUINTANA LOPEZ, «La organización municipal en el nuevo sistema de fuentes del Régimen local", en Rev. Española de Derecho administrativo n. ${ }^{\circ} 58$, págs 261 ss. 
Este sistema normativo que diseña la LBRL puede estimarse poco satisfactorio ofreciendo una complejidad innecesaria, con falta de precisión y claridad, como lo prueba que ante las dudas suscitadas con la publicación del Reglamento de Organización, Funcionamiento y Régimen Jurídico haya sido preciso acudir a criterios interpretativos tan poco ortodoxos como la resolución de la Dirección General de Administración local del Ministerio para las Administraciones públicas de 27 de enero de 1987 (BOE 28.1.1987) acerca de la «posición ordinamental» del citado Reglamento.

En todo caso, esta insólita resolución interpretativa de la Administración estatal «sobre posición ordinamental del Real Decreto 2568/1986, de 26 de noviembre..." 42 ha venido a confirmar abiertamente el sistema normativo que se expone, aunque es de indicar que efectúa una serie de distingos, a modo de conclusión, totalmente innecesarios y que contribuyen a confundir más que a facilitar la comprensión del sistema.

La organización de las entidades locales de existencia facultativa queda remitida a la normativa autonómica o, en su defecto, a las normas estatales de aplicación supletoria. En principio, por tanto, es un ámbito normativo reservado a la competencia de las Comunidades autónomas (arts. 42 y ss, LBRL).

Esta regulación que a nivel de legislación básica se contiene el la LBRL, al margen de los problemas que suscita de inconstitucionalidad -cuestión sobre la que necesariamente volveremos más adelante-, presenta aspectos criticables. Por un lado, por cuanto que muchos de sus preceptos, excesivamente reglamentarios, no deberían tener carácter de normativa básica, tal como ha sido señalado por algún sector de la doctrina 43; en ocasiones la LBRL regula de forma tan acabada determinados aspectos de la organización y funcionamiento de las entidades locales, imponiendo un criterio rígido y uniforme para todo el Estado ${ }^{44}$, que hace que su carácter básico sea muy discutible. Por otro lado, se puede decir que peca por defecto ya que no contiene toda la normativa básica, como lo prueba que el Texto Refundido promulgado

42 Para F. SOSA WAGNER, Manual de Derecho local (Madrid, 1987) pág. 52 «llama la atención la necesidad de tal resolución y mucho más que tan humilde fuente jurídica se permite aclarar la posición ordinamental de un Real Decreto».

43 Cfr. S. MARTIN-RETORTILlO, "La actuación de las Corporaciones locales,,,", op. cit. pág. 366.

44 Ello puede estimarse que está en contra del criterio manifestado por el Tribunal Constitucional al entender que "la fijación de estas condiciones básicas no puede implicar en ningún caso el establecimiento de un régimen uniforme para todas los entidades locales 
POTESTAD ORGANIZATORIA Y AUTONOMIA LOCAL

por R.D. 781/1986, de 18 de abril, en virtud de la autorización conferida al Ejecutivo por la Disposición Final Primera de la LBRL, contenga a su vez, disposiciones básicas tal como precisa la Disposición Final Séptima de dicho Texto refundido. Este planteamiento -que trae su causa del inciso final de la Disposición Transitoria Primera de la LBRL de redacción poco precisa- es desafortunado y complica innecesariamente la cuestión ${ }^{45}$. La normativa básica, al menos inicialmente, debería encontrarse contenida exclusivamente en la LBRL, una vez que el Estado ha hecho uso de su competencia normativa. Si algún precepto de la legislación anterior -que permaneciera vigente por no oponerse, contradecir o resultar incompatible con la nueva regulación (Disposición Derogatoria de la LBRL) - se entendiera que debe tener carácter básico, su lógica ubicación debería ser la LBRL. El contenido del Texto refundido quedaría así limitado a la legislación estatal no básica, de carácter transitorio y aplicación supletoria en defecto de la normativa de desarrollo que pudieran dictar las Comunidades autónomas. Ello contribuiría a facilitar el principio de seguridad jurídica ${ }^{46}$.

Aun admitiendo que algún contenido de la legislación anterior no derogada pueda tener carácter básico y como tal así recogerlo expresamente en el Texto refundido, en virtud de la autorización conferida por la Disposición Transitoria Primera y la Disposición Final Primera de la LBRL, es muy discutible que ello pueda darse en materia organizativa ${ }^{47}$, como pretende el Real Decreto 781/86, de 18 de abril. En

de todo el Estado, sino que debe permitir opciones diversas" (S.T.C. 28 de julio 1981); así mismo, está en contra de lo que proclama la Exposición de Motivos de la LBRL cuando se pronuncia en favor de "la constricción del marco legal a lo estrictamente indispensable para satisfacer el interés nacional".

45 Cfr. L. MORELL, El Derecho local español I, op. cit. pág. 157. Una explicación acerca de los contenidos básicos del texto refundido en J.M. BAN̂O LEON, «La ordenación de las normas reguladoras del Régimen local», en Tratado de Derecho municipal I (Madrid 1988) págs. 345 y ss.

46 Prueba de lo que se indica puede encontrarse en la resolución interpretativa de la $\mathrm{Di}$ rección General de Administración Local sobre «posición ordinamental del Real Decreto 2568/86", a que antes se ha hecho referencia, que incurre en la contradicción de decir que «las normas incluidas en el texto refundido como las que contienen los textos actualizados de los Reglamentos citados en la Disposición Final Primera de la ley 7/85, de 2 de abril, constituyen derecho estatal de carácter supletorio (art. 149.18 de la Constitución) y su vigencia resulta ser transitoria pues está condicionada, en términos generales, a la entrada en vigor de la normativa autonómica que venga a sustituirlo" (Apartado 4). Si contiene normas básicas ello no puede ser así.

47 Esta es la postura de G. FERNANDEZ FARRERES, La potestad local de auto-organización, op. cit. pág. 756-758 y que estimo correcta. En contra F. MERCADAL VIDAL "Organización municipal», op. cit. pág. 875. 
todo caso puede estimarse que incurre en abierta extralimitación llevando la normativa básica más allá de la delegación legislativa prevista en la LBRL (Disposición Final Primera), e incidiendo en ultra vires, con el posible control jurisdiccional no sólo por parte del Tribunal Constitucional, sino también por los Tribunales del orden contencioso-administrativo, tal como con carácter general ha reconocido el Tribuna Supremo en su Sentencia de 19 de diciembre de 1990. (Sala $3^{a}$ ) ${ }^{48}$.

\section{LA SENTENCIA DEL TRIBUNAL CONSTITUCIONAL 214/1989, DE 21 DE DICIEMBRE, EN RELACION A LA PO- TESTAD ORGANIZATORIA DE LAS ENTIDADES LOCALES}

El sistema normativo descrito acerca de la potestad organizatoria de los entes locales diseñado por la LBRL, sufre una mutación transcendental a consecuencia de la Sentencia del Tribunal Constitucional $214 / 1989$, de 21 de diciembre, que expulsa del ordenamiento jurídico determinados preceptos de la regulación que efectúa la ley básica en esta materia.

Dicha Sentencia es pronunciada a consecuencia de 4 recursos de inconstitucionalidad acumulados, planteados por el Parlamento y la Junta de Galicia y por el Parlamento y la Generalidad de Cataluña. Los 4 recursos, a los efectos que ahora interesan, impugnaban el artículo $5 \mathrm{~A}$ ) y los artículos 20 y 32, que son los que establecen la regulación de la potestad organizatoria de las entidades locales, tal como se ha visto.

Con esta Sentencia se confirman algunas de las dudas acerca de la constitucionalidad de ciertos aspectos de la regulación de la LBRL. aunque otros sigan en meros planteamientos de inconstitucionalidad por no haber recaído sobre ellos pronunciamiento del Tribunal Constitucional, ya que no han sido objeto de impugnación ${ }^{49}$.

\footnotetext{
48 Un comentario de dicha Sentencia y del control jurisdiccional de los excesos de la delegación legislativa en L. MARTIN REBOLLO, "Impugnación de la vigente ley de Régimen local por pretendido exceso en la delegación legislativa" en La Ley n. ${ }^{\circ} 2745$ (16 de mayo de 1991).

49 Así sucede con la composición de la Comisión Municipal de Gobierno, regulada en los arts. 20 y 23 de la LBRL y que viene a sustituir a la tradicional Comisión Municipal Permanente. Se trate de un órgano que pretende lograr «un claro reforzamiento de la posición del Alcalde en el ámbito del Ayuntamiento" y que supone "una inversión importante de la tradición municipal española» tal como reconoce F. SOSA WAGNER, "El nuevo régimen local en España", en Rev. Valenciana d'Estudis autonómics n. ${ }^{\circ} 1$, pág. 65 . Integrada por el Alcalde y un número de concejales no superior al tercio del número legal de los mismos, «nombrados y separados libremente" por el Alcalde, es este último rasgo el que
} 
POTESTAD ORGANIZATORIA Y AUTONOMIA LOCAL

En efecto, el Tribunal Constitucional entiende que la regulación establecida por la LBRL "contradice frontalmente el orden constitucional de distribución de competencias" entre el Estado y las Comunidades autónomas y depura el contenido de la ley básica en los términos siguientes, que se contienen en los Fundamentos Jurídicos 5 y 6:

- Por un lado, declarando inconstitucional el artículo 5- que con carácter general establece el sistema de fuentes jurídicas y que en relación a los aspectos organizativos efectuaba, en concreto, su apartado A) - B Bien entendido que la anulación en este caso no se produce porque dicho apartado A) contradiga el orden constitucional -ya que simplemente formulaba una declaración de carácter general sin mayores precisiones, que no incidía directamente en inconstitucionalidad-. Se limitaba a decir que "en cuanto a su régimen organizativo y de funcionamiento de sus órganos" las entidades locales "se rigen en primer término por la presente ley y además... por las leyes de las Comunidades autónomas sobre régimen local y por el Reglamento orgánico de cada entidad en los términos previstos en esta ley"; lo que en sí mismo no puede considerarse contrario a la Constitución.

En este caso la declaración de inconstitucionalidad se produce por motivos distintos que alcanzan a todo el contenido del artículo 5 y no solo al apartado A). El Tribunal Constitucional entiende que el precepto tiene "naturaleza de norma meramente interpretativa, sin contenido material alguna, la que hace al precepto constitucionalmente ilegítimo. El orden de fuentes de un ordenamiento compuesto es el establecido por el bloque de la constitucionalidad, sin que uno de los elementos de esa

se cuestiona desde el punto de vista constitucional, por atentar al pluralismo político en cuanto valor jurídico fundamental (Art. 1.1 de la C.E.) y al principio de representación (art. 23 C.E,). Si el Tribunal Constitucional en su Sentencia 35/85, de 6 de marzo (recurso de amparo 573/83) reconoció el derecho de los concejales de todo grupo político municipal a formar parte de las Comisiones Informativas con arreglo a criterios de proporcionalidad y tal principio se recoge en el art. 20.3 de la LBRL (Comisiones que son meros órganos internos sin competencias resolutorias), con mucha más razón dicha presencia habrá de ser necesaria en un órgano principal como es la Comisión de Gobierno. La falta de representación de todos los grupos políticos integrantes de la Corporación tan sólo, en el mejor de los casos, podría admitirse si se configura a la Comisión de Gobierno como simple órgano de asistencia y apoyo del Alcalde. Pero desde el momento que la Comisión de Gobierno aparece con posibilidad de ostentar competencias resolutorias por delegación del Pleno (Art. 26 LBRL), la falta de representación por parte de todos los grupos municipales supone una clara conculcación de principios constitucionales, a pesar de que la Jurisdicción Contencioso-administrativa no lo haya sabido ver asi. (Sentencia T.S., Sala $3^{a}$, de 11 de marzo de 1986). Si el derecho de información corresponde a todos los grupos con representación en el Ayuntamiento con mayor razón el derecho a participar en las decisiones. Recientemente, el Tribunal Constitucional ha vuelto a afirmar el principio del pluralismo político como "valor jurídico fundamental», deduciendo del mismo importantes consecuencias (S.T.C. 163/1991, de 18 de julio). 
realidad compuesta, en este caso el legislador estatal, pueda imponer a todos los demás, como única interpretación posible, la que él mismo hace». Y más adelante precisa:

«El artículo 5 ...establece, como queda dicho, un orden de prelación de fuentes que será correcto en la medida en que coincida con lo dispuesto en el bloque de la constitucionalidad e incorrecto en cuanto se aparte de él. En cuanto tal coincidencia exista, el precepto es en consecuencia superfluo y en cuanto no exista invalido. Su anulación no origina por tanto vacío normativo alguno» 50 .

Se trata de incidir en una línea argumental que el T.C. ya utilizó en su sentencia de 5.8.1983 acerca de la LOAPA.

- Por el contrario, los artículos 20 y 32 de la LBRL en cuanto relegan las normas autonómicas en materia de organización "a una posición secundaria, de orden subsidiario o supletorio en cuanto a su eficacia" respecto del Reglamento orgánico de la propia entidad son considerados contrarios a la Constitución. En consecuencia, el Tribunal Constitucional procede a depurar ambos preceptos (arts. 20 y 32) de aquellos incisos en virtud de los cuales el espacio normativo de las Comunidades autónomas... queda... virtualmente desplazado en su totalidad por la prevalencia de los reglamentos orgánicos complementarios de que puedan dotarse, según esta ley, los propios municipios". De esta forma entiende el Tribunal Constitucional que "depurado el precepto de los dos incisos... permite que éste se ajuste al orden constitucional de distribución de competencias, pues en el mismo se definen los órganos básicos municipales- (se está refiriendo al artículo 20 relativo a los órganos municipales, pero lo afirmado en relación a este precepto lo hace extensivo más adelante al artículo 32 que regula la organización de la entidad provincial)_-, se reconoce la potestad legislativa de desarrollo de las Comunidades autónomas y se admite al propio tiempo la existencia de un ámbito reservado a la autonomía organizativa municipal, ámbito este que no podrá ser desconocido o invadido por las normas que, en materia de organización municipal complementaria, dicten las Comunidades autónomas» 51.

50 Una severa crítica a la postura del Tribunal Constitucional en este punto puede verse en F. MORA BONGERA, "Régimen jurídico de las entidades locales. La incidencia de la sentencia del Tribunal Constitucional 215-89, de 21 de diciembre, sobre el sistema de fuentes", Rev. Española de Derecho Administrativo n. ${ }^{\circ}$ 70, págs. 279-280.

51 Con ello el Tribunal Constitucional ha venido a dar el mismo tratamiento, aplicando idénticos criterios, a los aspectos organizativos y a los competenciales, en contra del criterio que doctrinalmente se había sostenido por influencia del derecho y la doctrina de la Alemania Federal; vid. S. MUÑOZ MACHADO, Derecho público de las Comunidades autónomas II, op. cit. pág. 194 
POTESTAD ORGANIZATORIA Y AUTONOMIA LOCAL

Esta postura del Tribunal Constitucional que en principio se presenta como clara y rectilínea, si se examina con atención ofrece una cierta contradicción ${ }^{52}$. En efecto, como queda indicado en los párrafos transcritos, después de sostener la preeminencia de la legislación autonómica que se deriva de la distribución competencial que establece el bloque de la constitucionalidad, después de mantener que la potestad legislativa de desarrollo de las Comunidades autónomas no puede quedar «desplazada... por la prevalencia de los reglamentos orgánicos» 53, se afirma que existe "un ámbito reservado a la autonomía organizativa municipal... que no podrá ser desconocido o invadido por las normas que, en materia de organización municipal complementaria, dicten las Comunidades autónomas". ¿Cuál es ese ámbito que no puede ser desconocido o invadido? ¿Qué ámbito puede quedar a la potestad de auto-organización de la propia entidad una vez que el Estado ha regulado la cuestión con detalle y cuando la Comunidad autónoma respectiva haya dictado su ley de Régimen local desarrollando en un segundo nivel normativo la regulación orgánico-constitucional?

En principio, la única garantía de ese ámbito reservado viene determinada por el hecho de que la organización complementaria ha de estar establecida necesariamente por el Reglamento orgánico de la propia entidad, sin que pueda venir fijada por norma heterónoma, por exigencia de la ley básica tal como ha quedado después de ser depurada por el intérprete constitucional. Pero ello no es óbice para que el contenido de dicho reglamento orgánico al establecer la organización complementaria pueda venir condicionado por la legislación autonómica de desarrollo de la ley básica estatal. Así como, entendemos, no existe reparo jurídico para que la ley autonómica se presente como legislación supletoria en defecto de las previsiones del Reglamento orgánico, a fin de cubrir las lagunas que puedan presentarse. Por consiguiente, la organización local complementaria no puede venir establecida directamente por la normativa autonómica como permitía la inicial redacción de la LBRL, pero sí indirectamente condicionar la organización que establezca el Reglamento orgánico de la propia entidad. En todo caso, la cuestión no es fácil. Puede decirse

52 Discrepa radicalmente de esta doctrina jurisprudencial F. MORA BONGERA, "Régimen jurídico de las entidades locales...», op. cit. págs. 283-285.

53 Bien entendido que los límites a la potestad auto-organizatoria local por parte de la legislación autonómica tan sólo podrán estar establecidos por «las leyes de las Comunidades autónomas sobre régimen local» tal como expresamente establecen los arts. 20.2 y 32.2 de la LBRL, con lo que el reglamento orgánico local no estará subordinado a los reglamentos autonómicos y lo mismo hay que decir en relación a las meras disposiciones administrativas estatales. Cfr. E. GARCIA DE ENTERRIA, T.R. FERNANDEZ, Curso de Derecho administrativo I (Madrid 1979) pág. 296. 
que si se respeta el orden competencial que establece el bloque de la constitucionalidad la potestad de auto-organización local desaparece prácticamente o al menos sufre considerablemente; por el contrario, si se defiende el principio de autonomía local y las exigencias que comporta en el plano organizativo no se respeta la distribución competencial entre el Estado y las Comunidades autónomas en materia de régimen local. La LBRL - hasta cierto punto con una lógica comprensible desde sus propios planteamientos-dio preminencia al principio de autonomía sobre la competencia legislativa autonómica en lo que se refiere a la regulación orgánico-institucional. Ello lo viene a reconocer el Abogado del Estado en las alegaciones que formula en contra de los recursos de inconstitucionalidad interpuestos contra la ley $7 / 85$, al indicar que el vaciamiento de competencias (de las Comunidades autónomas) si bien está proscrito con carácter general nada impide que en un punto concreto pueda producirse, máxime cuando se trata precisamente de la protección de la autonomía... Para más adelante sostener que "dada la autonomía constitucionalmente garantizada se produce una falta de espacio competencial a favor de las Comunidades autónomas».

Por el contrario, el Tribunal Constitucional puso de relieve en toda su plenitud el orden constitucional de distribución de competencias con escrupuloso respeto a las que son propias de las Comunidades autónomas.

La tensión entre ambos principios queda reflejada en el hecho de que el Tribunal no mantiene una posición unánime en este punto. Existe, en efecto, un voto particular de Magistrado Sr. Díaz Eimil que discrepa de la Sentencia, colocándose en el punto de vista que adopta la LBRL, defendiendo la solución que consagra el texto impugnado partiendo del principio de autonomía local y sus exigencias. Y así sostiene "que la naturaleza supletoria y residual de esa competencia autonómica viene necesariamente determinada por la garantía de la autonomía municipal, la cual exige de manera insoslayable que las Comunidades autónomas no puedan cubrir más espacio organizativo municipal complementario que aquél que el municipio no haya completadon. Entiende que la doctrina jurisprudencial que por mayoría se establece viene a reconocer a las Comunidades autónomas «una especie de competencia básica de segundo grado que, aparte de incurrir en la contradicción conceptual de compatibilizar lo básico con lo complementario, altera substancialmente el modelo constitucional de organización municipal en la medida en que admite la posibilidad de que el poder complementario de auto-organización de los municipio encuentre límites mas allá del marco básico establecido por el legislador estatal que es el único que tiene competencia para 
POTESTAD ORGANIZATORIA Y AUTONOMIA LOCAL

establecerlo» 54 . Es de indicar que tal postura del Magistrado Díaz Eimil se refiere exclusivamente al municipio ya que considera «que sería muy discutible reconocer a la provincia el mismo nivel de autonomía».

La dificultad de la cuestión, en cierta forma, viene acrecentada por la conceptuación y sentido de la LBRL que pretende presentarse con una "superioridad ordinamental», con una "vis específica», tal como manifiesta su propia Exposición de Motivos, de la que carece y lógicamente le niega la Sentencia del Tribunal Constitucional (Fundamento Jurídico 5). El sistema que establece la LBRL no puede ser plenamente satisfactorio porque parte de criterios y fórmulas doctrinales propios de un Estado compuesto distinto del que diseña nuestro bloque constitucional 55; se intenta colocar al Estado en el papel de los Länder alemanes que son los competentes en materia de régimen local, quedando las Comunidades autónomas desplazadas, sin espacio competencial normativo en este ámbito organizativo.

A la vista del fallo del Tribunal Constitucional cobra todavía más fuerza la objeción que puede hacerse a la ley básica de regular con excesivo detalle los aspectos comunes de la organización local. El mínimo común denominador normativo (así lo denomina el Fundamento Jurídico 5 de la Sentencia del T.C. de 21 de diciembre de 1989) 56 , que ha de ser una ley básica, resulta excesivo dada la competencia de desarrollo que corresponde a las Comunidades autónomas ${ }^{57}$. O éstas no ejercen

54 La tesis que se formula en este voto particular se considera certera, desde el punto de vista de las exigencias de la autonomía local que garantiza la Constitución, por parte de F. ROMERO HERNANDEZ, "La Sentencia del Tribunal Constitucional de 21 de diciembre y los reglamentos orgánicos municipales", en Rev. Andaluza de Administración pública n. ${ }^{\circ}$ 1, pág. 83; también la comparte F. MORA BONGERA, "Régimen jurídico de las entidades locales...», op. cit. pág. 284, para quien «el voto particular da de lleno en la llaga, aunque sin llegar a las conclusiones definitivas que su razonamiento exige».

55 Se confirma ello si tenemos presente que L. PAREJO, Estado social y Administrativo pública (Madrid 1983) pág. 189, venía sosteniendo que el sistema español toma del federalismo alemán la nota estructural por cuanto "la Administración local es una institución territorial orgánicamente interiorizada por las Comunidades autónomas a través de los Estatutos de autonomía... (aunque) la interiorización por la instancia autonómica de la organización local no es completa en el sentido de traer causa directa de la Constitución y ser capaz de obviar toda incidencia directa del legislador estatal».

56 La Sentencia del T.C. de 28 de abril de 1983 utiliza la expresión "elementos normativos uniformes o denominador común". La expresión "denominador común normativo", para referirse a la legislación básica, arranca de la S.T.C. de 23 de enero de 1983.

57 Como señala L. MORELL, Régimen local español I, op. cit., pág. 139, «el problema, en el plano de la política legislativa, estriba en medir y calibrar el alcance de lo que ha de ser común a fin de no reducir en demasía lo que, también en el plano estrictamente político, se reconozca como marco para el auto-gobierno local y la creación propia de reglas de derecho". 
la competencia que les corresponde en este ámbito organizativo o la potestad de auto-organización prácticamente puede desaparecer con grave deterioro del principio de autonomía local; si la autonomía hace referencia a la gestión de sus propios intereses (art. 137 de la C.E.) ello «exige que se dote a cada ente de todas las competencias propias y exclusivas que sean necesarias para satisfacer el interés respectivo" 58 y es indudable que el que el primer y fundamental interés de una entidad hará referencia a la libertad para establecer la organización adecuada a sus propias exigencias y características ${ }^{59}$.

Cuando efectivamente una Comunidad autónoma ejerza su competencia y apruebe una ley de Régimen local que desarrolle los preceptos básicos en materia de organización -salvo que lo haga con carácter puramente supletorio, concediendo total libertad a la entidad local para establecer los órganos complementarios que estime pertinentes-, la disponibilidad normativa de las entidades locales podrá desaparecer prácticamente. La única solución para salvar las graves consecuencias que para la autonomía local podrían derivarse de esta situación es que las propias leyes autonómicas se presenten con el carácter de derecho puramente supletorio, sin condicionar de ningún modo el contenido del Reglamento orgánico.

Así sucede, al menos, en los casos de las Comunidades autónomas de Cataluña, Canarias y Murcia que han aprobado sus correspondientes leyes de Régimen local. Prescindiendo de que la ley 6/1988, de 25 de agosto, de Régimen local de la Región de Murcia pueda haber ido más allá de la competencia que le corresponde por tratarse de un Estatuto de autonomía menor, es indudable que tanto en este caso como en el de la ley Municipal y de Régimen local de Cataluña de 15 de abril de 1987 y en el de la ley de Régimen Jurídico de las Administraciones públicas de Canarias de 18 de noviembre de 1986, se trata de regulaciones pensadas para un supuesto radicalmente diferente del que resulta de la sentencia del Tribunal Constitucional. No obstante, en la práctica no se

58 Vid. F. SOSA WAGNER, Manual de Derecho local, op. cit., pág. 60.

59 Así lo entienden F. ROMERO HERNANDEZ, "La Sentencia del Tribunal Constitucional...», op. cit., pág. 417 y F. MORA BONGERA, «Régimen jurídico de las entidades locales...", op. cit., pág. 274. Aunque la Constitución no reconozca de forma expresa la potestad de auto-organización a las entidades locales, a diferencia de lo que sucede con las Comunidades autónomas (art. 148.1.1 ${ }^{\mathrm{a}}$ ), es indudable que debe reputarse como un poder implícito en todo ente del que se predique la autonomía, como núcleo y expresión de la misma. Sobre el alcance de potestad autonómica de "organización de sus instituciones de autogobierno" vid. SS TC 5.81983 (F.J.3) y 8.61989 (F.J.7c) y el estudio reciente de J.L. CARRO, "Sobre la potestad autonómica de auto-organización", en REDA n..$^{\circ}$ 11, pág. 317 ss. 
crean mayores problemas dado el criterio a que responde la redacción de las leyes autonómicas que están pensadas para ser aplicadas en defecto de Reglamento orgánico al que expresamente la ley territorial reconoce como normativa aplicable antes que sus propios contenidos. Asi sucede con la ley de Régimen Jurídico de las Administraciones públicas de Canarias:

«1. La organización y funcionamiento de los municipios canarios se regirá por la legislación básica de Régimen local y por sus respectivos Reglamentos orgánicos.

2. En defecto de Reglamento propio la organización y funcionamiento de los municipios canarios se regirá... por los preceptos contenidos en los artículos siguientes" (artículo 56) 60.

En caso contrario, si la ley territorial pretendiera condicionar la regulación que debe efectuar el Reglamento orgánico de la propia entidad, este recorte o limitación de la autonomía local puede considerarse contrario a la garantía institucional propia de la Administración local 61 . Sobre todo, si se diera el caso de que la ley autonómica condicione de tal forma el contenido del Reglamento orgánico que excluya toda posibilidad de decisión por parte de la entidad local, ya que en tal supuesto no se reconocería el ámbito reservado a la autonomía municipal a que se refiere la Sentencia del Tribunal Constitucional 62.

\footnotetext{
$60 \mathrm{El}$ segundo apartado de este precepto puede plantear problemas en la medida en que va más allá de la pura supletoriedad para cubrir las lagunas que pueden presentarse, pretendiendo aplicarse en defecto de Reglamento orgánico, dada la redacción con que queda la legislación básica después de la depuración efectuada por el interprete constitucional. Según dicha redacción los órganos complementarios han de estar establecidos y regulados "por los propios municipios en sus Reglamentos orgánicos».
}

En sentido análogo el artículo 21 de la ley de Murcia. Más problemática resulta el alcance que presenta la regulación que efectúa la ley territorial catalana; una exposición de su contenido puede verse en F. MERCADAL, «Organización municipal», op. cit., págs. 911 y ss.

61 Tal como la ha recogido el Tribunal Constitucional en su sentencia de 28 de julio de 1981, partiendo de la formulación de CARL SCHMITT en base al artículo 27 de la Constitución de Weimar. Sobre la aplicación a las entidades locales de esta garantía, vid. L. PAREJO, Garantía institucional y autonomías locales (Madrid 1982), op. cit., passim.

$62 \mathrm{Si}$ la autonomía tiene sus propias características y exigencias en razón del ente del que se trate (S.T.C. de 27 de febrero de 1987 en relación a la autonomía universitaria), es indudable que formando parte del núcleo de la misma hay que incluir una cierta libertad de auto-organización que la garantía institucional ha de salvaguardar ya que debe formar parte del "reducto indisponible o núcleo esencial de la institución" (S.T.C. 28.7. 1981). Garantía institucional que tratándose de las entidades locales presenta la limitación derivada de la imposibilidad de impugnación directa de las leyes -ya sean 
Por otro lado, la configuración de la potestad organizatoria local a partir de la Sentencia del Tribunal Constitucional puede conferir al régimen local una extremada rigidez y uniformidad, abortando toda posibilidad al llamado régimen de carta 63 y ello a pesar de la apelación a la historia y a la tradición de que hace gala la Exposición de Motivos de la LBRL ${ }^{64}$. Si ciertamente la fórmula tuvo siempre fuertes condicionamientos 65 , que impidieron su efectiva aplicación práctica ${ }^{66}$, en un momento en que se reconoce el principio de autonomía local con especial énfasis no debiera cercenarse de raíz sus posibilidades.

El estudio que queda realizado acerca del poder de organización en el ámbito de las Administraciones locales permite constatar el corto alcance que presenta la potestad auto-organizatoria en nuestro ordenamiento jurídico, siendo ello el lógico resultado de la posición institucional de las entidades locales dentro de la organización territorial del

estatales o autonómicas - que atenten a su autonomía, en contra de lo que sucede en otros ordenamientos jurídicos. "La sensibilidad del legislador básico", a que se refiere SOSA WAGNER, Manual de Derecho local, op. cit. pág. 63, en este punto no le dio más opción, ante las limitaciones que se derivan del texto constitucional, que la solicitud por parte de la Comisión Nacional de Administración local a los órganos constitucionalmente legitimados para que interpongan el recurso correspondiente; algo que evidentemente puede hacer dicha Comisión o cualquier entidad local, dígalo o no lo diga la ley básica. Sobre las dificultades y limitaciones de la garantía de la autonomía local vid. J. LEGUINA, "La autonomía de municipios y provincias en la nueva ley básica de Régimen local», en Rev. de Estudios de la Vida local y autonónica n $^{\circ} 227$, págs. 334-335; M. ARAGON, “El tratamiento constitucional de la autonomía local», op. cit., págs. 492-493 y J. RODRIGUEZ ZAPATA, «La defensa de la autonomía local ante el Tribunal Constitucional y los Tribunales ordinarios», en La provincia en el sistema constitucional (Madrid 1991), págs. 465 ss.

63 Instaurado con el Estatuto municipal de Calvo Sotelo de 1924 (arts. 42 y ss.) es considerado por ORTIZ DIAZ como "suprema manifestación de potestad normativa» (Modalidades y perspectivas del régimen de Carta, Madrid 1954) pág. 51.

64 Una de las escasa quiebras al principio de uniformidad organizativa es la del Concejo abierto, partiendo de su reconocimiento constitucional (art. 140 in fine de la Constitución) y que entraña excepcionar la organización necesaria establecida por el derecho común básico (art. 19.1 LBRL). Los regímenes municipales especiales (art. 30 LBRL) y la organización de las grandes ciudades (Madrid y Barcelona, Disposición Adicional Sexta LBRL) presentan muy escasas posibilidades en el aspecto orgánico, dada la redacción de los correspondientes preceptos de la ley estatal básica.

65 Las limitaciones que presentaba el Régimen de Carta en la legislación de 1955 no fueron consideradas opuestas a la Constitución, tal como declaró el Tribunal Constitucional (S. 2 de febrero de 1981, Fundamento Jurídico 5) «ya que la autonomía garantizada para la gestión de los respectivos intereses no parece que tenga que comprender el poder dotarse de un gobierno o administración distinto del previsto con carácter general por la ley, sin control alguno».

$66 \mathrm{Cfr}$. A. EMBID IRUJO, Ordenanzas y reglamentos municipales en el derecho español (Madrid 1978), pág. 688 y ss. 
POTESTAD ORGANIZATORIA Y AUTONOMLA LOCAL

Estado, tal como aparece configurada en el Título VIII de la Constitución, y clara manifestación del contenido real de la autonomía local. En efecto, el alcance de la potestad organizatoria local, con la carga polémica que se ha visto y que presentan inequívocamente los temas organizativos, como Sebastián MARTIN-RETORTILLO apunta con lucidez ${ }^{67}$, es el resultado de la tensión y enfrentamiento entre los principios de autonomía local y de competencia autonómica sobre el régimen local, ambos garantizados constitucionalmente, y que se resuelve por el Tribunal Constitucional en favor del segundo por la Sentencia 214/89, de 21 de diciembre, expresión - una más- del trato que reciben las instituciones autonómicas y locales en nuestro ordenamiento jurídico.

67 Vid. S. MARTIN RETORTILLO «El tema de la autonomía provincial: las Diputaciones y el proceso autonómico" en Rev. de Estudios de la Vida Local y autonómica n. ${ }^{\circ} 248$, pág. 681. 
REAL-1992, núm. 255-256. VALLINA VELARDE, JUAN LUIS DE LA. POTESTAD ORGANIZATORIA Y AUTONO... REAL-1992, núm. 255-256. VALLINA VELARDE, JUAN LUIS DE LA. POTESTAD ORGANIZATORIA Y AUTONO... 